\title{
Uretiana silviae sp.n. - new Cossidae (Lepidoptera) species from Northern Argentina
}

\section{Uretiana silviae sp.n. - новый вид Cossidae (Lepidoptera) из Северной Аргентины}

\author{
R.V. Yakovlev ${ }^{1,2}$, A.E. Naydenovi, F.C. Penco ${ }^{3}$ \\ Р.В. Яковлев ${ }^{1,2}$, А.Е. Найденов ${ }^{1}$, Ф.Ц. Пенко ${ }^{3}$
}

\footnotetext{
${ }^{1}$ Altai State University, pr. Lenina 61, Barnaul,656049 Russia. E-mail: colias24@mail.ru; yakovlev_asu@mail.ru

${ }^{2}$ Tomsk State University, Laboratory of Biodiversity and Ecology, Lenina pr. 36, 634050 Tomsk, Russia. E-mail: yakovlev_asu@mail.ru

${ }^{3}$ Fundación de Historia Natural "Félix de Azara", Departamento de Ciencias Naturales y Antropología, Universidad Maimónides, Hidalgo 775 piso 7 (1405BDB) Ciudad Autónoma de Buenos Aires, Argentina. E-mail: fernando_penco@hotmail.com

${ }^{1}$ Алтайский государственный университет, пр. Ленина 61, Барнаул 656049, Россия.

${ }^{2}$ Томский государственный университет, Лаборатория биоразнообразия и экологии, пр. Ленина 33, Томск 634050, Poccия. E-mail: yakovlev_asu@mail.ru
}

KEY WORDS: entomology, Carpenter moths, Hypoptinae, fauna, Southern America, Neotropics, taxonomy. КЛЮЧЕВЫЕ СЛОВА: энтомология, древоточцы, Нурорtinae, фауна, Южная Америка, неотропики, таксономия.

ABSTRACT. The article describes a new species, Uretiana silviae Yakovlev, Naydenov et Penco sp.n. (type locality: NW Argentina, Jujuy Prov., Santa Barbara Mts., 12 km SW Palma Sola, Eco Portal De Piedra NP) (Lepidoptera, Cossidae: Hypoptinae). The descriptions are provided with a detailed diagnosis and illustrations.

РЕЗЮМЕ. В статье описан новый вид Uretiana silviae Yakovlev, Naydenov et Penco sp.n. (type locality: NW Argentina, Jujuy Prov., Santa Barbara Mts., 12 km SW Palma Sola, Eco Portal De Piedra NP) (Lepidoptera, Cossidae: Hypoptinae). Описание сопровождается подробным диагнозом и проиллюстрировано.

\section{Introduction}

Carpenter moths (Lepidoptera, Cossidae) of the subfamily Hypoptinae Neumoegen and Dyar (1894) with the type genus Hypopta Hübner, 1818 (type species Hypopta ambigua Hübner, 1818) are endemic for the New World. The are mostly common in South America, only a few species reach North to Mexico and southern states of the US. Schoorl [1990] included nine valid genera into the subfamily: Hypopta Hübner, 1818 (= Dolecta Herrich-Schäffer, [1854], Philanglaus Butler, 1882, Breyeriana Orfila, 1957), Langsdorfia Hübner, [1821], Philiodoron Clench, 1957, Givarbela Clench, 1957 (= Shausisca Gentili, 1985),
Pomeria Barnes, McDunnough, 1911, Givira Walker, 1956 (=Eugivira Schaus, 1901, Lentagena Dyar, 1905, Stenocyttara Turner, 1918, Acyttara Turner, 1918, Anastomophleps Hering, 1923), Psychogena Schaus, 1911, Puseyia Dyar, 1940, and Inguromorpha Edwards, 1888 (= Ravigia Dyar, 1905). Basing on a detailed study of the male genital structure, we established the status of several already described genera and described a series of new taxa of generic and species range [Penco, Yakovlev, 2017; Penco, Yakovlev, Naydenov, 2019, 2020; Penco et al., 2019; Yakovlev, Naydenov, Penco, 2019].

The genus Uretiana Yakovlev, Naydenov et Penco, 2019 (type species - Givira vicuñensis Ureta, 1957) was described by the authors within the revision of the group of taxa Hypoptinae having the bifurcated uncus [Yakovlev, Naydenov, Penco, 2019]. In addition to the type species, this genus includes: U. tucumana Yakovlev, Naydenov et Penco, 2019 and U. infans (Dyar et Schaus, 1937). The genus is widespread in the subtropical zone of South America in Brazil, Paraguay and Argentina. The species biology of the genus is unknown, except for the adult flight periods: FebruaryMarch and September-October.

\section{Material and methods}

Adults of Cossidae were collected using light traps. Male genitalia were mounted in euparal on

How to cite this article: Yakovlev R.V., Naydenov A.E., Penco F.C. 2020. Uretiana silviae sp.n. - new Cossidae (Lepidoptera) species from Northern Argentina // Russian Entomol. J. Vol.29. No.3. P.295-297. doi: 10.15298/rusentj.29.3.09 
slides following Lafontaine and Mikkola [Lafontaine, Mikkola, 1987; Lafontaine, 2004]. The adults were photographed using a digital camera Canon EOS $600 \mathrm{D}$. The genitalia preparations were photographed using a Olympus DP74 camera attached to an Olympus SZX16 stereomicroscope. The type material of the new species is deposited in Zoological Institute (Sankt-Petersburg, Russia).

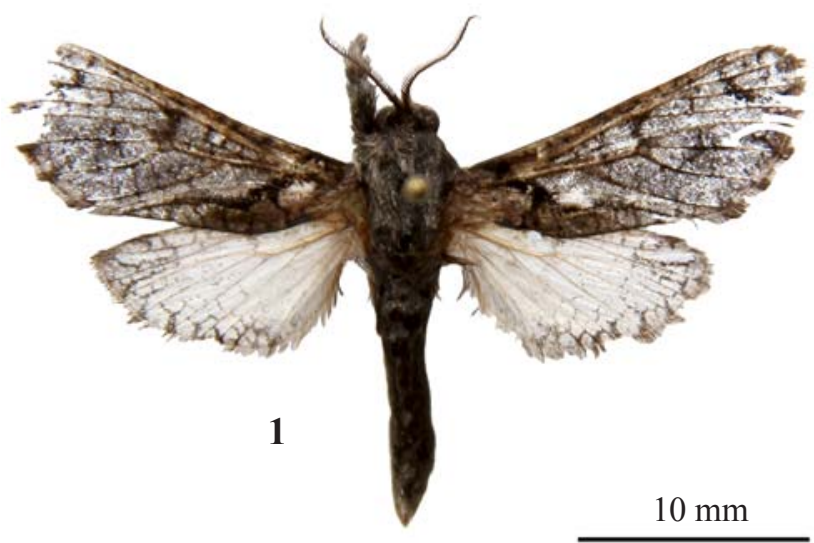

\section{Taxonomical part}

Uretiana silviae Yakovlev, Naydenov et Penco, sp.n. Figs 1-3.

MATERIAL. Holotype (Zoological Institute, Sankt-Petersburg, Russia), O', NW Argentina, Jujuy Prov. Santa Barbara Mts. $12 \mathrm{~km}$ SW Palma Sola, Eco Portal DePiedra NP, $24^{\circ} 05^{\prime} 42,5^{\prime \prime} \mathrm{S}$ $064^{\circ} 23^{\prime} 56,8^{\prime \prime} \mathrm{W}, \mathrm{H}-1045 \mathrm{~m}, 19-22.10 .2019$, R. Yakovlev, V. Doroshkin, S. Reshetnikov leg. Slide № 288 coll. A. Naydenov.

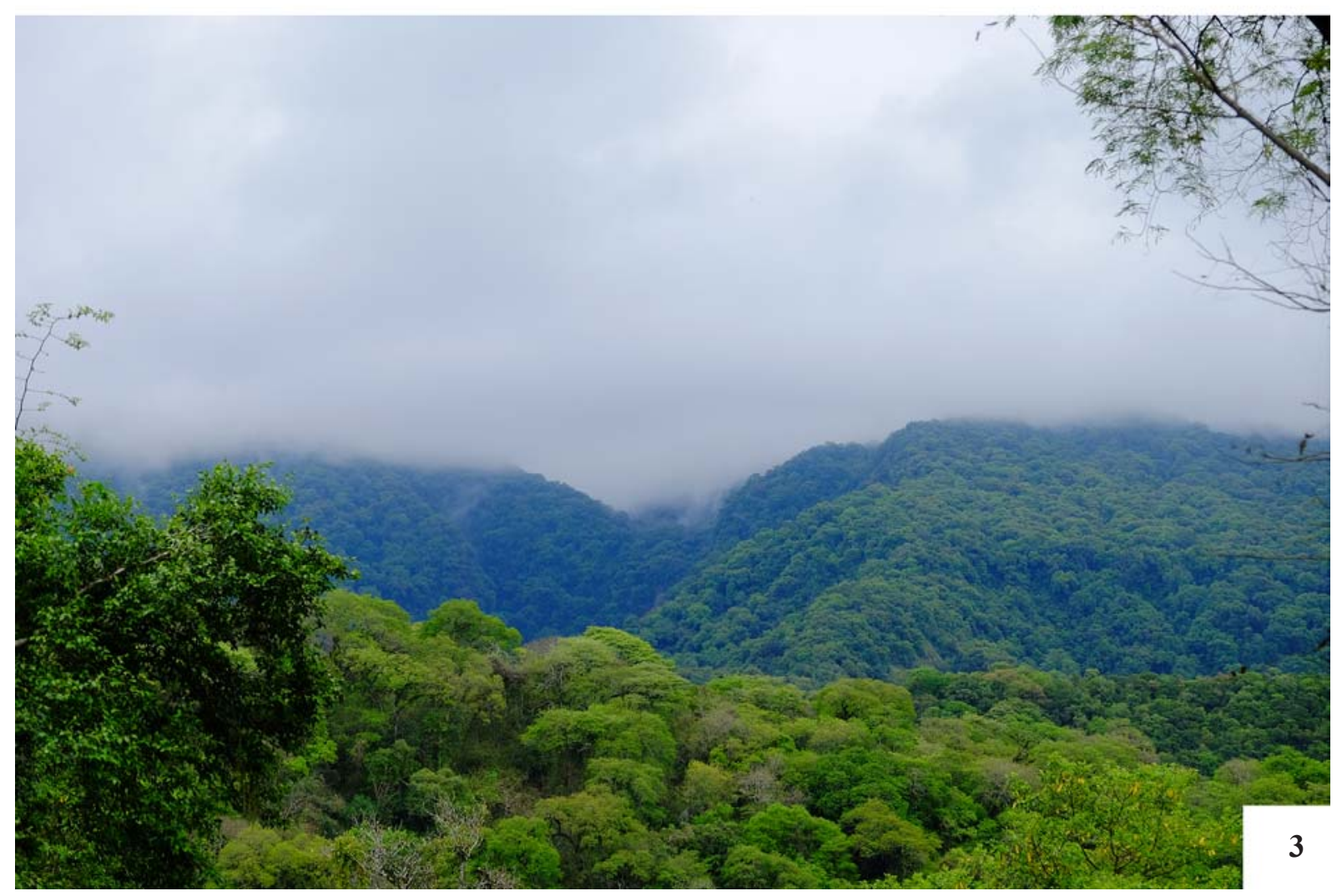

Figs 1-3. Uretiana silviae Yakovlev, Naydenov et Penco, sp.n.: 1 - Holotype (Zoological Institute, Sankt-Petersburg, Russia); 2 - Male genitalia, slide ${ }^{1} 288$ coll. A. Naydenov; 3 - Habitat (photo by Sergey Reshetnikov).

Рис. 1-3. Uretiana silviae Yakovlev, Naydenov et Penco, sp.n.: 1 - Голотип (Зоологический иинститут, Санкт-Петербург, Россия); 2 - Гениталии самца, постоянный препарат № 288 coll. A. Naydenov; 3 - Биотоп (фото С. Решетникова). 
DESCRIPTION. Length of fore wing $15.5 \mathrm{~mm}$. Antenna relatively short, about $1 / 3$ of fore wing in length, bipectinate (crest processes short in medium third of antenna, about 1.3 of antenna rod diameter). Thorax and tegulae covered with grey scales. Fore wing grey with poorly expressed lightbrown pattern (oblique stroke at root, spot in discal cell apically, poorly expressed strokes postdiscally and submarginally). Hind wing white with thin grey undulated lines and strokes postdiscally and submarginally.

Male genitalia. Uncus large, long, split into two halves up to base; gnathos arms completely absent; valve semicircular basally with two apical processes: the first short, apically semicircular, the second long, strongly curved on border of basal and medium thirds, distal third sickle-curved, with sharp apex, from which a leaf-like membranous part outcomes; semicircular, basally wide harpe in medium third of basal part of the valve; juxta tiny; phallus $1 / 4$ shorter than valve, slightly curved in medium third, two short wedge processes on distal end, vesica aperture in dorso-apical position, vesica without cornuti, coecum membranous, bag-like.

Female unknown.

DIAGNOSIS. The new species differs from the other representatives of the genus in the following characters:

- from U. vicunensis (Ureta, 1957) - in the longer fore wing, lighter pattern and very small process on the valve;

- from U. tucumana Yakovlev, Naydenov et Penco, 2019

- in the poorly expressed reticulated pattern on the fore wing, longer apical process on the valve, longer saccus, longer and more curved phallus;

- from U. infans (Dyar et Schaus, 1937) - in the absence of the postdiscal dark area on the fore wing (cubitally), less curves arms of the uncus, longer and more curved phallus, and the short apical process on the valve;

- from all the known representatives of the genus the new species differs in the apical process of the valve, strongly curved on the border of basal and medium thirds.

ETYMOLOGY. The new species is named after Silvia Strelkov (Palma Sola, Argentina) - the director of private nature reserve Eco Portal De Piedra National Park.

Acknowledgements. The authors are grateful to Carlos Cuñado Strelkov, Silvia Strelkov and Carlos Cuñado (Palma
Sola, Argentina) for their assistance in studying the entomofauna of the province Jujuy in Northern Argentina. We also express our sincere gratitude to the companions of the first author during his expedition to Argentina: Vyacheslav Doroshkin (Chelyabinsk, Russia) and Sergey Reshetnikov (Novosibirsk, Russia). The authors are also grateful to Dr. Anna K. Ustjuzhanina (Tomsk, Russia) for linguistic corrections of the manuscript.

Competing interests. The authors declare no competing interests.

\section{References}

Lafontaine J.D. 2004. Noctuoidea, Noctuidae (part), Noctuinae (part-Agrotini) // Hodges R.W. (ed.). The Moths of America North of Mexico. Fasc. 27.1. Washington: The Wedge Entomological Research Foundation. 385 pp.

Lafontaine J.D., Mikkola K. 1987. Lock-and-key system in the inner genitalia of Noctuidae (Lepidoptera) as taxonomic character // Entomologiske Meddelelse. Vol.55. P.161-167.

Penco F.C., Yakovlev R.V. 2017. Descripción de una nueva especie de Cossidae de Argentina (Lepidoptera: Cossoidea: Cossidae: Hypoptinae) // Historia Natural, Tercera Serie. Vol.7. No.2. P.67-76.

Penco F.C., Yakovlev R.V., Naydenov A.E. 2019. New species of genus Breyeriana Orfila, 1957 (Lepidoptera: Cossidae: Hypoptinae) from Argentina // Ecologica Montenegrina. Vol.20. P.114118.

Penco F.C., Yakovlev R.V., Naydenov A.E., Witt T.J. 2019. Two new species of the genus Givarbela Clench, 1957 (Lepidoptera: Cossidae: Hypoptinae) from South Neotropics // Zootaxa. Vol.4577. No.3. P.596-600.

Penco F.C., Yakovlev R.V., Naydenov A.E. 2020. A new Genus and new Species of Carpenter-Moths (Lepidoptera: Cossidae: Hypoptinae) from southern Argentina // Russian entomological Journal. Vol.29. No.2. P.210-213. doi: 10.15298/rusentj.29.2.16

Schoorl J. W. 1990. A phylogenetic study on Cossidae (Lepidoptera: Ditrysia) based on external adult morphology // Zoologische Verhandelingen. Vol.263. P.4-295.

Yakovlev R.V., Naydenov A.E., Penco F.C. 2019. New data on Neotropical Carpenter-Moths of Subfamily Hypoptinae Neumoegen, Dyar, 1894 (Lepidoptera: Cossidae). I. New taxa with bifurcated uncus // Ecologica Montenegrina. Vol.26. P.4-13. 